\title{
Pengaruh Pengendalian Diri, Motivasi, Perilaku dan Minat Belajar terhadap Tingkat Pemahaman Akuntansi
}

\section{(Studi Empiris Pada Mahasiswa IAI Nusantara Batanghari dan Universitas Dinamika Bangsa Jambi)}

\author{
Dini Haryati, Ayu Feranika \\ IAI Nusantara Batanghari Muara Bulian, Universitas Dinamika Bangsa Jambi \\ diniharyati14@gmail.com
}

\begin{abstract}
This study aims to determine the effect of self-control, motivation, interest, and learning behavior on the level of accounting comprehension. The population in this study were students of IAI Nusantara Batanghari and Dinamika Bangsa Jambi University. The number of students at the Faculty of Economics at the final level for IAI Nusantara Batanghari amounted to 50 people, and students at the University of Dinamika Bangsa Jambi majoring in computerized accounting were 30 people. The sampling technique in this study is saturated sampling technique, where all the population is sampled, so that the total sample in this study amounted to 80 people. The technique of distributing questionnaires was carried out online via google from the students of IAI Nusantara Batanghari and Dinamika Bangsa Jambi University. The data analysis used in this research is multiple regression analysis with the help of a computer through the SPSS 20.0 for Windows program. The results showed that self-control, motivation, learning behavior had an effect on the level of understanding of accounting, only interest in learning had no effect on the level of understanding of accounting. But simultaneously shows all the independent variables of this study; self-control, motivation, learning behavior and interest in learning have an effect on the dependent variable, namely; level of accounting understanding.
\end{abstract}

Keywords- Motivation, Behavior, Interest in Learning, Level of Accounting Understanding

Abstrak- Penelitian ini bertujuan untuk mengetahui Pengaruh Pengendalian Diri, Motivasi, Minat, dan Perilaku Belajar Terhadap Tingkat Pemahaman Akuntansi. Populasi dalam penelitian ini adalah mahasiswa-mahasiswa IAI Nusantara Batanghari dan Universitas Dinamika Bangsa Jambi. Jumlah mahasiswa Fakultas Ekonomi ditingkat akhir untuk IAI Nusantara Batanghari berjumlah 50 orang, dan mahasiswa Universitas Dinamika Bangsa Jambi jurusan komputerisasi akuntansi berjumlah 30 orang. Teknik pengambilan sampel pada penelitian ini adalah dengan teknik sampling jenuh, dimana semua populasi yang dijadikan sampel, sehingga total sampel pada penelitian ini berjumlah 80 orang. Teknik penyebaran kuesioner dilakukan secara online melalui google from kepada mahasiswa Mahasiswa IAI Nusantara Batanghari dan Universitas Dinamika Bangsa Jambi. Analisis data yang digunakan adalam penelitian adalah analisis regresi berganda dengan bantuan komputer melalui program SPSS 20.0 for Windows. Hasil Penelitian menunjukkan pengendalian diri, motivasi, perilaku belajar berpengaruh terhadap tingkat pemahaman akuntansi hanya minat belajar yang tidak berpengaruh terhadap tingkat pemahaman akuntansi. Tetapi secara simultan menunjukkan semua variabel independen penelitian ini ; pengendalian diri, motivasi, perilaku belajar dan minat belajar berpengaruh terhadap variabel dependen, yaitu ; tingkat pemahaman akuntansi.

Kata Kunci- Pengendalian Diri, Motivasi, Perilaku, Minat Belajar, Tingkat Pemahaman Akuntansi

\section{PENDAHULUAN}

Perguruan tinggi akuntansi yang menghasilkan lulusan dalam bidang akuntansi saat ini dituntut untuk tidak hanya menghasilkan lulusan yang menguasai kemampuan di bidang akademik, tetapi juga mempunyai kemampuan yang bersifat teknis analisis dalam bidang humanistic skill (kemampuan menghadirkan diri secara manusiawi dalam kehidupan masyarakat yang turut bertanggungjawab bagi kelangsungan nilai-nilai kemanusiaan dan kemasyarakatan) dan professional skill (kemampuan melaksanakan profesinya dengan berbekalkan pengetahuan akademik yang memadai dalam rangka mengaktualisasikan dirinya di masyarakat) sehingga mempunyai nilai tambah dalam bersaing di dunia kerja (Budhiyanto dan Nugroho, 2004:260).

Tingkat pemahaman akuntansi mahasiswa dinyatakan dengan seberapa mengerti mahasiswa terhadap apa yang sudah dipelajari dalam konteks ini mengacu pada mata kuliah akuntansi. Tingkat pemahaman akuntansi menjadi sangat penting karena dapat diketahui seberapa cukuplah ilmu akuntansi yang sudah dimiliki seorang akuntan agar bisa melaksanakan 
peran akuntan di dunia bisnis. Tanda seorang mahasiswa memahami akuntansi tidak hanya ditunjukan dari nilainilai yang didapatkannya dalam mata kuliah tetapi juga apabila mahasiswa tersebut mengerti dan menguasai konsep terkait.

Perilaku belajar mahasiswa saat di perguruan tinggi mempengaruhi tingkat pemahaman akuntansi. Namun, di Indonesia proses belajar yang sedang berjalan pada umumnya belum bisa dipandang sebagai proses belajar mandiri (Suwardjono, 2004:7). Dosen menetapkan sumber pengetahuan apa saja yang perlu dipelajari oleh mahasiswa dalam bentuk silabus atau program belajar, kemudian mahasiswa menjalani program belajar tersebut, dan dosen yang mengendalikan proses belajar mahasiswa.

Hasil pengamatan yang dilakukan peneliti pada waktu mengikuti perkuliahan menunjukan bahwa mata kuliah akuntansi merupakan mata kuliah yang dianggap sulit oleh para mahasiswa karena memerlukan pemahaman, kecermatan, dan ketelitian dalam menganalisis setiap transaksi yang terjadi di perusahaan. Kompetensi yang dipelajari dalam akuntansi saling berkaitan dan berupa satu kesatuan. Apabila penguasaan mahasiswa pada kompetensi sebelumnya kurang, maka dimungkinkan mahasiswa akan sulit menguasai kompetensi selanjutnya, keberhasilan prestasi belajar akuntansi ditentukan oleh beberapa faktor yang berkaitan dengan kebiasaan belajarnya.

Perilaku belajar yang baik dapat terwujud apabila mahasiswa sadar akan tanggung jawab mereka sebagai mahasiswa, sehingga mereka dapat membagi waktu mereka dengan baik antara belajar dengan kegiatan di luar belajar. Motivasi dan pengendalian diri sangat penting dalam hal ini karena motivasi merupakan arah bagi pencapaian yang ingin diperoleh dan disiplin merupakan perasaan taat dan patuh pada nilai-nilai yang diyakini dan melakukan pekerjaan dengan tepat jika dirasa itu adalah sebuah tanggung jawab (Tenisia et al., 2020). Sundem (1993) dalam Sari (2013) mengkhawatirkan akan ketidakjelasan pada industri akuntansi yang dihasilkan oleh pendidikan tinggi akuntansi, hal ini dikarenakan banyak perguruan tinggi tidak mampu membuat anak didiknya menguasai dengan baik pengetahuan dan keterampilan hidup. Mahasiswa terbiasa dengan pola belajar menghafal tetapi tidak memahami pelajaran tersebut, sehingga mahasiswa akan cenderung mudah lupa dengan apa yang pernah dipelajari atau kesulitan untuk memahami apa yang diajarkan selanjutnya.

Minat belajar selama di perguruan tinggi juga mempengaruhi prestasi akademik seorang mahasiswa. Minat belajar mahasiswa erat kaitannya dengan penggunaan waktu yang baik untuk belajar maupun kegiatan lainnya (Andriani et al., 2020). Minat belajar yang tinggi akan dapat terwujud apabila mahasiswa sadar akan tanggung jawab mereka sebagai mahasiswa, sehingga mampu meningkatkan motivasi dan disiplin diri agar mampu mencapai target yang diinginkan dalam memahami suatu materi yang berhubungan dengan akuntansi.

Akuntansi bukanlah bidang studi yang anya menggunakan angka-angka dan menghitung penjumlahan atau pengurangan, akan tetapiakuntansi juga merupakan bidang studi yang menggunakan penalaran yang membutuhkan logika. Seorang mahasiswa yang memiliki kecerdasan emosional khususnnya yang meliputi pengendalian diri dan motivasi yang baik akan berdampak positif terhadap perilaku belajarnya, karena mahasiswa tersebut akan mampu menghadapi tekanan atau kesulitan yang datang dengan terus belajar tanpa putus asa sehingga dapat lebih mudah dan akan lebih memahami akuntansi. Pemahaman mata kuliah akuntansi yang baik akan mempengaruhi kemampuan mahasiswa pendidikan akuntansi saat terjun ke dunia kerja.

Berdasarkan latar belakang diatas peneliti tertarik untuk melakukan penelitian tentang fenomena tingkat pemahaman akuntansi, maka penulis tertarik untuk mengangkat judul penelitian sebagai berikut "Pengaruh Pengendalian Diri, Motivasi, Minat, dan Perilaku Belajar Terhadap Tingkat Pemahaman Akuntansi (Studi Empiris Pada Mahasiswa IAI Nusantara Batanghari dan Universitas Dinamika Bangsa Jambi)”. 


\section{Pengendalian Diri}

\section{KAJIAN PUSTAKA}

Goleman (2001), Pengendalian diri adalah kemampuan menangani emosi diri sehingga berdampak positif pada pelaksanaan tugas, peka terhadap kata hati, sanggup menunda kenikmatan sebelum tercapainya suatu sasaran, dan mampu segera pulih dari tekanan emosi. Menurut Goleman (2001), seseorang yang dapat mengendalikan diri mereka dapat mengelola dan mengekspresikan emosi yang ditandai dengan adanya:

a. Dapat menangani emosi, sehingga emosi dapat diekspresikan dengan tepat.

b. Mempunyai toleransi terhadap frustrasi.

c. Menangani ketegangan jiwa dengan lebih baik.

Semakin tinggi tingkat kemampuan mahasiswa dalam mengendalikan atau mengelola emosinya maka semakin baik tingkat pemahaman terhadap ilmu akuntansinya. Semakin baik pengendalian diri yang dilakukan oleh mahasiswa akan memungkinkan mahasiswa akan memperoleh hasil belajar yang baik dalam hal ini adalah pemahaman akuntansi mahasiswa.

Berdasarkan definisi diatas, maka dapat disimpulkan yang dimaksud pengendalian diri adalah kemampuan untuk mengelola emosi, desakkan hati, berhati-hati, bertanggung jawab, cerdas dalam mengatur kehidupan sesuai dengan norma untuk menghadapi dan informasi-informmasi yang baru. Adapun indikator dari pengendalian diri ini terdiri dari :

1. Mengendalikan Emosi

2. Sifat dapat Dipercaya

3. Kewaspadaan

4. Adaptibilitas

5. Inovasi

Perilaku Belajar

Perilaku belajar menurut Syah (2005:106) dalam Sari (2013:4) adalah peristiwa ikatan antara stimulus respon dan melibatkan proses kognitif. Prinsip belajar memberi indikasi serta arahan mengenai perilaku belajar. Azwar (2004:24) menjelaskan yang mendasari orang berperilaku menjadi tiga komponen yang saling menunjang, yaitu:
1. Kognitif, menyangkut pengetahuan yang biasanya digunakan dalam proses berfikir.

2. Afektif, menyangkut kehidupan emosional seseorang yang mewarnai pengetahuan serta gagasan yang terdapat dalam komponen kognitif yang meliputi nilai rasa baik atau tidak baik, suka atau tidak suka.

3. Konatif, merupakan kecendrungan untuk bertingkah laku dengan cara tertentu terhadap suatu keadaan.

Motivasi (Motivation)

Motivasi adalah kemampuan menggunakan hasrat agar setiap saat dapat membangkitkan semangat dan tenaga untuk mencapai keadaan yang lebih baik, serta mampu mengambil inisiatif dan bertindak secara efektif. Unsur-unsur motivasi, yaitu:

a. Dorongan prestasi (achievement drive), yaitu dorongan untuk menjadi lebih baik atau memenuhi standar keberhasilan.

b. Komitmen (commitmen), yaitu menyesuaikan diri dengan sasaran kelompok atau lembaga.

c. Inisiatif (initiative), yaitu kesiapan untuk memanfaatkan kesempatan.

d. Optimisme (optimisme), yaitu kegigihan dalam memperjuangkan sasaran kendati ada halangan dan kegagalan.

Minat Belajar

Minat merupakan rasa ketertarikan, perhatian, keinginan lebih yang dimiliki seseorang terhadap suatu hal, tanpa ada dorongan. Minat tersebut akan menetap dan berkembang pada dirinya untuk memperoleh dukungan dari lingkungannya yang berupa pengalaman. Pengalaman akan diperoleh dengan mengadakan interaksi dengan dunia luar, baikmelalui latihan maupun belajar. Dan faktor yang menimbulkanminat belajar dalam hal ini adalah dorongan dari dalam individu. Dorongan motif sosial dan dorongan emosional.Dengan demikiandisimpulkan bahwa pengertian minat belajar adalah kecenderungan individu untuk memiliki rasa senangtanpa ada paksaan sehingga dapat menyebabkan perubahan pengetahuan, ketrampilan dan tingkah laku. Pemahaman Akuntansi

Rissyo dan Nurna (2006:9) Seseorang yang memiliki pemahaman akuntansi adalah seseorang yang 
pandai dan mengerti benar akuntansi. Mardahlena (2007) dalam Arie (2009:23) "Tingkat pemahaman akuntansi mahasiswa dinyatakan dengan seberapa mengerti seseorang mahasiswa terhadap apa yang sudah dipelajari yang dalam konteks ini mengacu pada mata kuliah akuntansi." Budhiyanto dan Ika (2004) dalam Anggun (2010:22), tingkat pemahaman pengantar akuntansi mahasiswa dinyatakan dengan seberapa mengerti seorang mahasiswa terhadap apa yang sudah dipelajari yang dalam konteks ini mengacu pada mata kuliah - mata kuliah akuntansi. Tanda seorang mahasiswa memahami akuntansi tidak hanya ditunjukkan dari nilai-nilai yang di dapatkannya dalam mata kuliah, tetapi juga apabila mahasiswa tersebut mengerti dan dapat menguasai konsep-konsep yang terkait.

Berdasarkan definisi diatas, maka dapat disimpulkan yang dimaksud dengan pemahaman akuntansi adalah proses atau cara mahasiswa jurusan akuntansi dalam memahami mata kuliah akuntansi. Mahasiswa dapat dikatakan menguasai atau memahami akuntansi apabila ilmu akuntansi yang sudah di perolehnya selama ini dapat diterapkan dalam kehidupannya bermasyarakat atau dengan kata lain dapat dipraktekkan didunia kerja.

Kerangka Berpikir

Kerangka pemikiran teoritis dalam penelitian ini adalah tentang Pengaruh Pengendalian Diri, Motivasi, Minat, dan Perilaku Belajar Terhadap Tingkat Pemahaman Akuntansi. Variabel penelitian yang digunakan dalam penelitian ini adalah variabel independen dan variabel dependen. Variabel independennya yaitu pengendalian diri, motivasi, minat, dan perilaku belajar. Variabel dependen dalam penelitian ini adalah tingkat pemahaman akuntansi.

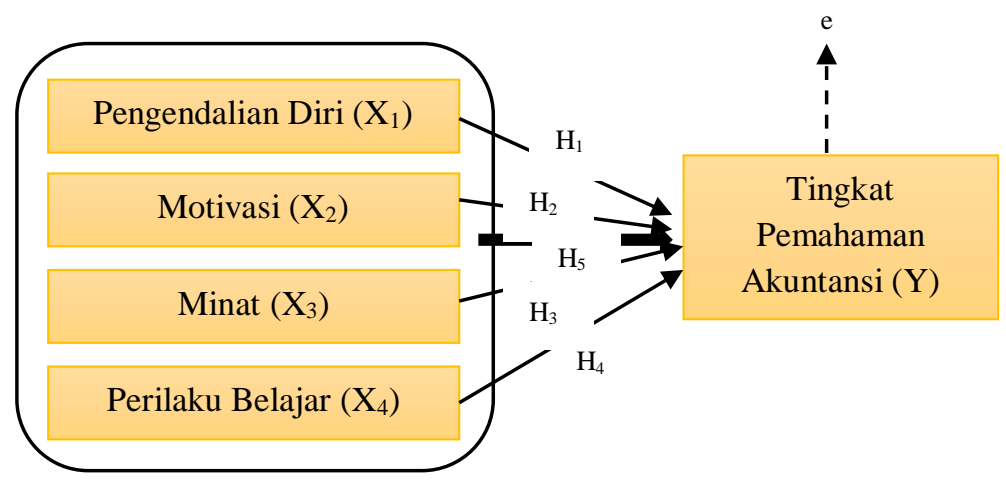

Gambar : Kerangka Berpikir Pengaruh Pengendalian Diri, Motivasi, Minat, dan Perilaku Belajar Terhadap Tingkat Pemahaman Akuntansi.

Keterangan :

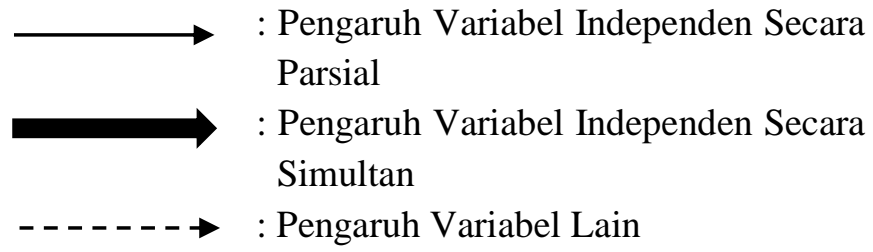

Perumusan Hipotesis

$\mathrm{H}_{1}$ : Pengendalian diri berpengaruh terhadap tingkat pemahaman akuntansi.

$\mathrm{H}_{2}$ : Motivasi berpengaruh terhadap tingkat pemahaman akuntansi.

$\mathrm{H}_{3}$ : Minat Belajar berpengaruh terhadap tingkat pemahaman akuntansi.

$\mathrm{H}_{4}$ : Perilaku Belajar berpengaruh terhadap tingkat pemahaman akuntansi.

$\mathrm{H}_{5}$ : Pengendalian diri, motivasi, minat belajar, dan Perilaku Belajar berpengaruh secara simultan terhadap tingkat pemahaman akuntansi.

\section{METODE PENELITIAN}

Populasi dan Sampel

Populasi dalam penelitian ini adalah mahasiswamahasiswa IAI Nusantara Batanghari dan Universitas Dinamika Bangsa Jambi. Jumlah mahasiswa Fakultas Ekonomi ditingkat akhir untuk IAI Nusantara Batanghari berjumlah 50 orang, dan mahasiswa Universitas Dinamika Bangsa Jambi jurusan komputerisasi akuntansi berjumlah 30 orang. Teknik pengambilan sampel pada penelitian ini adalah dengan teknik sampling jenuh, dimana semua populasi yang dijadikan sampel, sehingga total sampel pada penelitian ini berjumlah 80 orang.

Jenis Data

Data yang digunakan dalam penelitian ini adalah data primer. Data primer didapat dari sumber primer. Sumber primer merupakan sumber data yang langsung memberikan data kepada pengumpul data (Sugiyono, 2010). Data primer dalam penelitian ini dalam bentuk persepsi atau jawaban responden yang diperoleh melalui

Teknik Pengumpulan Data penyebaran kuesioner. 
Data sekunder diperoleh dengan melakukan studi pustaka untuk mengumpulkan data dari buku-buku referensi, artikel, jurnal ilmiah yang berhubungan dengan masalah yang diteliti dan akan digunakan sebagai landasan pemikiran teoritis. Sedangkan data primer diperoleh dengan menggunakan kuesioner, yaitu teknik pengumpulan data dengan cara memberi seperangkat pertanyaan atau pernyataan tertulis kepada responden untuk dijawabnya (Sugiyono, 2010). Teknik penyebaran kuesioner dilakukan dengan penyebaran kuesioner secara online melalui google from kepada mahasiswa Mahasiswa IAI Nusantara Batanghari dan Universitas Dinamika Bangsa Jambi.

Instrumen Penelitian

Instrumen yang digunakan dalam penelitian ini adalah angket. Untuk mengukur variabel Pengendalian diri $\left(\mathrm{X}_{1}\right)$, Motivasi $\left(\mathrm{X}_{2}\right)$, Minat Belajar $\left(\mathrm{X}_{3}\right)$, Perilaku belajar $\left(\mathrm{X}_{4}\right)$, digunakan angket dengan alat ukur menggunakan skala Likert. Diukur dengan menggunakan skala dengan skor 5 s/d 1 poin, yaitu: Sangat Setuju (SS), Setuju (S), Kurang Setuju (KS), Tidak Setuju (TS), dan Sangat Tidak Setuju (STS). Sedangkan tingkat pemahaman akuntansi (Y) digunakan nilai dari mata kuliah akuntansi. Langkah-langkah yang dilakukan dalam pembuatan angket ini adalah menentukan indikator-indikator variabel kemudian ditentukan sub indikator dan selanjutnya dijabarkan dalam bentuk item-item pernyataan untuk memperoleh kesesuaian butir.

Operasional Variabel Penelitian

Variabel penelitian ini terdiri dari variabel bebas (Independen), yaitu ; Pengendalian diri $\left(\mathrm{X}_{1}\right)$, Motivasi $\left(\mathrm{X}_{2}\right)$, Perilaku belajar $\left(\mathrm{X}_{3}\right)$, Minat Belajar $\left(\mathrm{X}_{4}\right)$,dan variabel terikat (Dependen) yaitu ; Pemahaman akuntansi (Y).

Untuk pengendalian diri $\left(\mathrm{X}_{1}\right)$ terdiri dari 10 item pertanyaan, Motivasi $\left(\mathrm{X}_{2}\right)$ terdiri dari 10 item pertanyaan Perilaku belajar $\left(\mathrm{X}_{4}\right)$ terdiri dari 20 pertanyaan, Minat Belajar $\left(\mathrm{X}_{4}\right)$ terdiri dari 25 item pertanyaan, dan Pemahaman akuntansi (Y) terdiri dari data nilai mata kuliah akuntansi.
Pengujian Kualitas Data

Dalam suatu penelitian, kesimpulan yang diambil akan sangat bergantung pada kualitas data yang dianalisis dan instrumen yang digunakan untuk mengumpulkan data penelitian, karena itu ada dua konsep yang dapat digunakan untuk mengukur kualitas data, yaitu : validitas dan reliabilitas.

Uji Asumsi Klasik

Model regresi yang baik harus memenuhi uji asumsi klasik, uji normalitas, uji heterokedastisitas dan uji multikolinieritas.

Metode Analisis Data

Analisis data yang digunakan adalam penelitian adalah analisis regresi berganda dengan bantuan komputer melalui program SPSS 20.0 for Windows. Persamaan yang digunakan adalah sebagai berikut :

$Y_{1}: Y=a+b_{1} X_{1}+b_{2} X_{2}+b_{3} X_{3}+b_{4} X_{4}+e$.

Keterangan :

Y : Tingkat Pemahaman Akutntansi

a : Konstanta

$\mathrm{b}_{1}-\mathrm{b}_{4} \quad$ : Koefisien Regresi Masing-masing Variabel

$X_{1} \quad$ : Pengendalian diri

$X_{2} \quad$ : Motivasi

$X_{3} \quad$ : Perilaku belajar

$X_{4} \quad$ : Minat belajar

e : Error

Pengujian Hipotesis

Pengujian hipotesis dalam penelitian ini menggunakan dan t (uji parsial) dan uji f (uji simultan). Pengujian dilakukan dengan menggunakan 2 tahap yakni

1. Tahap 1 : Adalah menguji hipotesis dengan Uji t. Uji t digunakan untuk mengetahui pengaruh masingmasing variabel independen terhadap variabel dependen. untuk menerima atau menolak hipotesis yang dirumuskan, yaitu dengan melihat signifikansi lebih kecil dari 0,05 maka $\mathrm{H}_{0}$ ditolak atau $\mathrm{H}_{\alpha}$ diterima artinya secara parsial variabel bebas tersebut berpengaruh secara signifikan terhadap variabel terikat (Ghozali, 2011).

2. Tahap 2 : Menguji model penelitian dengan Uji F. Model penelitian dapat dikatakan fit Uji Probabilitas signifikansi $<0,05$. 


\section{HASIL ANALISIS DATA DAN PEMBAHASAN}

\section{Profil Responden}

Sebanyak 80 kuesioner pada penelitian ini disebarkan kepada responden yaitu 30 mahasiswa Universitas Dinamika Bangsa Jambi jurusan komputerisasi akuntansi dan 50 orang mahasiswa IAI Nusantara Batanghari Fakultas Ekonomi. Setiap responden menjawab Untuk pengendalian diri terdiri dari 10 item pertanyaan, Motivasi terdiri dari 10 item pertanyaan Perilaku belajar terdiri dari 20 pertanyaan, Minat Belajar terdiri dari 25 item pertanyaan, dan Pemahaman akuntansi terdiri dari 5 data nilai mata kuliah akuntansi. Distribusi kuesioner dan tingkat pengembalian tercantum dalam tabel berikut :

Tabel 4.1

Jumlah Sampel dan Tingkat Pengembalian

\begin{tabular}{|l|c|}
\hline \multicolumn{1}{|c|}{ Penyebaran Kuesioner } & Jumlah \\
\hline Kuesioner yang disebar & 80 \\
\hline Kuesioner yang kembali & 78 \\
\hline Kuesioner yang tidak kembali & 2 \\
\hline Kuesioner yang dapat diolah & 72 \\
\hline Kuesioner yang tidak dapat diolah & 6 \\
\hline Tingkat pengembalian kuesioner & $9,08 \%$ \\
\hline
\end{tabular}

Sumber : Data Primer yang Diolah, 2020

Keterangan pada tabel 4.1 tersebut menunjukkan bahwa tingkat pengembalian kuesioner sebesar 93,08\% atau 78 kuesioner, yang berarti sebagian besar kuesioner yang disebar kembali pada peneliti. Kuesioner yang dapat diolah sebanyak 72 kuesioner. Hal ini menunjukkan bahwa responden pada penelitian ini cukup memiliki pemahaman dan keseriusan untuk memberikan persepsinya terhadap kuesioner yang diisi. Uji Asumsi Klasik

Uji Normalitas

Tabel 4.2

One-Sample Kolmogorov-Smirnov Test

\begin{tabular}{|ll|r|}
\hline & & $\begin{array}{c}\text { Unstandardized } \\
\text { Predicted Value }\end{array}$ \\
\hline $\mathrm{N}$ & Mean & 72 \\
Normal Parameters & a,b & 18,5409302 \\
& Std. Deviation & 2,30158795 \\
Most Extreme Differences & Absolute &, 062 \\
& Positive &, 047 \\
& Negative &,- 062 \\
Kolmogorov-Smirnov Z & &, 404 \\
Asymp. Sig. (2-tailed) & &, 997 \\
\hline
\end{tabular}

Hasil Uji Normalitas a. Test distribution is Normal.

b. Calculated from data.

Sumber: Hasil Pengolahan Data, 2020

Berdasarkan hasil pengujian One Sample Kolmogorov-Smirnov Test, dapat dilihat bahwa nilai Asymp. Sig (2-Tailed) lebih besar dari 0,05 yaitu 0,997 sehingga dapat dinyatakan bahwa data berdistribusi secara normal. Dengan demikian asumsi normalitas taksiran model yang diperoleh terpenuhi.

Uji Multikolinearitas

Tabel 4.3

Hasil Uji Multikolinearitas

\begin{tabular}{|c|c|c|}
\hline \multirow[b]{2}{*}{ Model } & \multicolumn{2}{|c|}{ Collinearity Statistics } \\
\hline & Tolerance & VIF \\
\hline $1 \quad$ (Constant) & & \\
\hline $\mathrm{X} 1$ & 685, & 1,459 \\
\hline X2 & 657, & 1,522 \\
\hline $\mathrm{X} 3$ & ,712 & 1,404 \\
\hline $\mathrm{X} 4$ & ,873 & 1,146 \\
\hline
\end{tabular}

a. Dependent Variable: $\mathrm{Y}$

Sumber: Hasil Pengolahan Data, 2018

Model regresi yang baik seharusnya tidak terjadi korelasi di antara variabel bebas. Diatas menunjukkan bahwa kedua variabel independen memiliki nilai Tolerance Value di atas 0,1 dan VIF kurang dari 10. Jadi dapat dinyatakan bahwa tidak ada multikolinieritas antar variabel independen dalam model regresi.

Uji Heteroskedastisitas

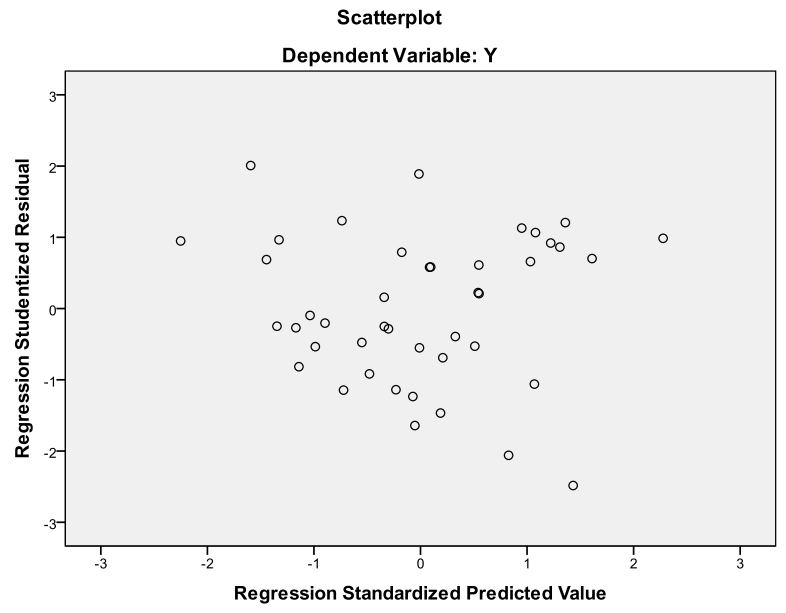

Gambar 4.1 
Grafik Uji Heteroskedastisitas Sumber: Hasil Pengolahan Data, 2020

Berdasarkan analisis grafik scatterplot pada gambar $4.1 \mathrm{di}$ atas menunjukkan tidak ada pola yang jelas, sehingga dapat dinyatakan bahwa data pada penelitian ini tidak terjadi heteroskedastisitas.

Hasil Analisis Regresi Linier Berganda

Tabel 4.4

Hasil Regresi Linier Berganda

Coefficients $^{\mathrm{a}}$

\begin{tabular}{|c|c|c|c|c|c|}
\hline \multirow[b]{2}{*}{ Model } & \multicolumn{2}{|c|}{$\begin{array}{l}\text { Unstandardized } \\
\text { Coefficients }\end{array}$} & \multirow{2}{*}{$\begin{array}{c}\begin{array}{c}\text { Standardize } \\
\mathrm{d} \\
\text { Coefficients }\end{array} \\
\text { Beta } \\
\end{array}$} & \multirow[b]{2}{*}{$\mathrm{t}$} & \multirow[b]{2}{*}{ Sig. } \\
\hline & B & $\begin{array}{l}\text { Std. } \\
\text { Error }\end{array}$ & & & \\
\hline 1 ) & 12,322 & 6,100 & & 2,020 & 050 \\
\hline $\mathrm{X} 1$ &,- 526 & 228 &,- 351 & $-2,304$ & ,027 \\
\hline $\mathrm{X} 2$ & ,306 & , 102 & ,468 & 3,007 & ,005 \\
\hline $\mathrm{X} 3$ & 281 & , 120 &, 351 & 2,347 & ,024 \\
\hline $\mathrm{X} 4$ &,- 131 & ,079 &,- 225 & $-1,666$ & ,104 \\
\hline
\end{tabular}

Dependent Variable: $\mathrm{Y}$

Sumber: Hasil Pengolahan Data, 2020

Berdasarkan keterangan pada tabel 4.4 maka diperoleh persamaan regresi sebagai berikut:

$Y=12,322-0,526 X_{1}+0,306 X_{2}+0,281 X_{3}-0,131 X_{4}$

Uji Hipotesis

Uji t

Tabel 4.5

Hasil Uji Statistik t

\begin{tabular}{|c|c|c|c|c|}
\hline \multirow{2}{*}{\multicolumn{2}{|c|}{ Model }} & \multirow[b]{2}{*}{$\mathrm{t}$} & \multirow[b]{2}{*}{ Sig. } & Hasil \\
\hline & & & & \\
\hline 1 & (Constant) & 2,020 &, 050 & \\
\hline & $\mathrm{X} 1$ & $-2,304$ & ,027 & $\mathrm{H}_{\mathrm{a}}$ diterima \\
\hline & $\mathrm{X} 2$ & 3,007 & ,005 & $\mathrm{H}_{\mathrm{a}}$ diterima \\
\hline & $\mathrm{X} 3$ & 2,347 & ,024 & $\mathrm{H}_{\mathrm{a}}$ diterima \\
\hline & $\mathrm{X} 4$ & $-1,666$ & ,104 & $\mathrm{H}_{\mathrm{a}}$ ditolak \\
\hline
\end{tabular}

a. Dependent Variable: Y

Sumber: Hasil Pengolahan Data, 2020

Berdasarkan tabel 4.5 dapat dijelaskan bahwa pengujian hipotesis adalah sebagai berikut:

$\mathrm{H}_{1}: \mathrm{t}_{\text {hitung }}$ 2,304 dan level sig 0,027 jika dibandingkan dengan $\alpha=0,05$ maka level sig $<\alpha(0,027<0,05)$ akibatnya $\mathrm{H}_{0}$ ditolak dan $\mathrm{H}_{\mathrm{a}}$ diterima. Hal ini berarti bahwa pengendalian diri berpengaruh signifikan tingkat pemahaman akuntansi.

$\mathrm{H}_{2}: \mathrm{t}_{\text {hitung }}$ 3,007 dan level sig 0,005 jika dibandingkan dengan $\alpha=0,05$ maka level sig $<\alpha(0,005<0,05)$ akibatnya $\mathrm{H}_{0}$ ditolak dan $\mathrm{H}_{\mathrm{a}}$ diterima. Hal ini berarti bahwa motivasi berpengaruh signifikan tingkat pemahaman akuntansi.

$\mathrm{H}_{3}: \mathrm{t}_{\text {hitung }}$ 2,347 dan level sig 0,024 jika dibandingkan dengan $\alpha=0,05$ maka level sig $<\alpha(0,024<0,05)$ akibatnya $\mathrm{H}_{0}$ ditolak dan $\mathrm{H}_{\mathrm{a}}$ diterima. Hal ini berarti bahwa perilaku belajar berpengaruh signifikan tingkat pemahaman akuntansi.

$\mathrm{H}_{4}: \mathrm{t}$ hitung 1,666 dan level sig 0,104 jika dibandingkan dengan $\alpha=0,05$ maka level sig $>\alpha(0,104>0,05)$ akibatnya $\mathrm{H}_{0}$ diterima dan $\mathrm{H}_{\mathrm{a}}$ ditolak. Hal ini berarti bahwa minat belajar tidak berpengaruh signifikan tingkat pemahaman akuntansi.

Uji f

Tabel 4.6

Hasil Uji Statistik f

ANOVA $^{\mathrm{b}}$

\begin{tabular}{|c|c|c|c|c|c|}
\hline Model & $\begin{array}{l}\text { Sum of } \\
\text { Squares }\end{array}$ & df & $\begin{array}{c}\text { Mean } \\
\text { Square }\end{array}$ & $\mathrm{F}$ & Sig. \\
\hline 1 Regression & 222,487 & 4 & 55,622 & 6,183 &, $001^{\mathrm{a}}$ \\
\hline Residual & 341,843 & 68 & 8,996 & & \\
\hline Total & 564,330 & 72 & & & \\
\hline
\end{tabular}

a. Predictors: (Constant), X4, X3, X1, X2

b. Dependent Variable: Y

Sumber: Hasil Pengolahan Data, 2020.

Berdasarkan tabel 4.6 di atas, maka diperoleh hasil sebagai berikut:

$\mathrm{H}_{5}$ : Nilai $\mathrm{F}=6,183$ dengan level sig $<\alpha(0,001 \mathrm{a}<$ 0,005), akibatnya $\mathrm{H}_{0}$ ditolak dan $\mathrm{H}_{\mathrm{a}}$ diterima. Jadi terbukti pengendalian diri dan perilaku belajar secara bersama-sama berpengaruh signifikan terhadap tingkat pemahaman akuntansi.

PEMBAHASAN

Pengaruh Pengendalian diri terhadap tingkat pemahaman akuntansi.

Hasil analisis regresi berganda menunjukkan bahwa hipotesis $1\left(\mathrm{H}_{1}\right)$ memberikan hasil $\mathrm{H}_{0}$ ditolak dan $\mathrm{H}_{\mathrm{a}}$ diterima, berarti pengendalian diri berpengaruh terhadap tingkat pemahaman akuntansi. Hal ini menunjukan bahwa semakin tinggi tingkat pengendalian diri mahasiswa, seperti mengendalikan emosi, sifat dapat 
dipercaya, kewaspadaan, adaptibilitas dan inovasi maka akan semakin tinggi pula tingkat pemahaman akuntansi.

Sejalan dengan yang dikemukakan oleh Goleman (2001:39), yang menyatakan bahwa pengendalian diri adalah kemampuan memantau dan menendalikan perasaan sendiri dan orang lain serta menggunakan perasaan-perasaan tersebut untuk memadu pikiran dan tindakan, sehingga pengendalian diri sangat diperlukan untuk sukses dalam bekerja dan menghasilkan kinerja yang menonjol dalam pekerjaan. Hasil penelitian ini juga sejalan dengan hasil penelitian Sari (2013) yang menyatakan pengendalian diri berpengaruh terhadap tingkat pemahaman pengantar akuntansi.

Motivasi berpengaruh terhadap tingkat pemahaman akuntansi.

Hasil analisis regresi berganda menunjukkan bahwa hipotesis $2\left(\mathrm{H}_{2}\right)$ memberikan hasil $\mathrm{H}_{0}$ ditolak dan $\mathrm{H}_{\mathrm{a}}$ diterima, berarti motivasi berpengaruh terhadap tingkat pemahaman akuntansi. Hal ini menunjukkan bahwa semakin tinggi tingkat motivasi mahasiswa, seperti dorongan prestasi, komitmen, inisiatif, dan optimisme maka akan semakin tinggi pula tingkat pemahaman akuntansi.

Sejalan dengan yang dikemukakan oleh Melandy \& Azizah (2006) dalam teorinya, Motivator yang paling berdaya guna adalah motivator dari dalam, bukan dari luar. Keinginan untuk maju dari dalam diri mahasiswa akan menimbulkan semangat dalam meningkatkan kualitas mereka. Para mahasiswa yang memiliki upaya untuk meningkatkan diri akan menunjukkan semangat juang yang tinggi ke arah penyempurnaan diri yang merupakan inti dari motivasi untuk meraih prestasi. Dengan demikian, motivasi yang tinggi berarti bahwa mahasiswa lebih memiliki keinginan untuk melakukan sebuah tindakan demi mencapai apa yang menjadi tujuannya.

Hasil Penelitian ini juga sejalan dengan Subowo dan Alien (2016) yang menyatakan bahwa motivasi belajar berpengaruh terhadap tingkat pemahaman akuntansi mahasiswa. Hasil penelitian Ishak (2013) juga menyatakan hal yang sama, yaitu motivasi belajar berpengaruh pada tingkat pemahaman akuntansi.

Perilaku Belajar berpengaruh terhadap tingkat pemahaman akuntansi.

Hasil analisis regresi berganda menunjukkan bahwa hipotesis $3\left(\mathrm{H}_{3}\right)$ memberikan hasil $\mathrm{H}_{0}$ ditolak dan $\mathrm{H}_{\mathrm{a}}$ diterima, berarti perilaku belajar berpengaruh terhadap tingkat pemahaman akuntansi. Hal ini menunjukkan bahwa semakin tinggi perilaku belajar mahasiswa, seperti kebiasaan mengikuti pelajaran, kebiasaan membaca buku, kunjungan ke perpustakaan dan kebiasaan mengahadapi ujian semakin tinggi atau baik pula tingkat pemahaman akuntansi.

Sejalan yang dikemukakan oleh Rampengan (1997) dalam Sari (2013) pada teorinya yang menyatakan bahwa dalam proses belajar diperlukan perilaku belajar yang sesuai dengan

tujuan pendidikan, dimana dengan perilaku belajar tersebut tujuan pendidikan dapat dicapai secara efektif dan efisien, sehingga prestasi akademik dapat ditingkatkan. Perilaku belajar sering juga disebut kebiasaan belajar yaitu merupakan proses belajar yang dilakukan individu secara berulang-ulang sehingga menjadi otomatis atau spontan.

Hasil penelitian ini juga sejalan dengan penelitian yang dilakukan Sari (2013), dan penelitian Subowo dan Alien (2016) yang menyatakan bahwa Perilaku blejara berpengaruh signifikan terhadap tingkat pemaham akuntansi.

Minat Belajar berpengaruh terhadap tingkat pemahaman akuntansi.

Hasil analisis regresi berganda menunjukkan bahwa hipotesis $4\left(\mathrm{H}_{4}\right)$ memberikan hasil $\mathrm{H}_{0}$ diterima dan $\mathrm{H}_{\mathrm{a}}$ ditolak, berarti minat belajar tidak berpengaruh terhadap tingkat pemahaman akuntansi. Hal ini menunjukkan bahwa semakin rendah kecenderungan hati, kesukaan ataupun keinginan yang bersifat aktif semakin rendah pula tingkat pemahan akuntansi.

Hasil tersebut tidak sejalan dengan teori yang dikemukakan Linda dan Sugeng (2017) dalam penelitiannya, bahwa minat merupakan variabel penting yang berpengaruh terhadap tercapainya sebuah prestasi atau cita-cita yang diharapkan, bahwa belajar dengan minat akan jauh lebih baik hasilnya, bila dibandingkan dengan belajar tanpa disertai dengan adanya minat.

Variabel ini menunjukkan hasil yang tidak sejalan dengan penelitian yang dilakukan Linda dan Sugeng (2017), dan penelitian Ishak (2013) yang menunjukkan hasil varibel minat belajar berpengaruh terhadap tingkat pemahaman akuntansi. Hal tersebut dapat terjadi dengan kemungkinan adanya kondisi dan keadaan yang berbeda pada responden. 
Pengaruh Pengendalian diri, Motivasi, Perilaku Belajar, dan Minat Belajar terhadap Tingkat Pemahaman Akuntansi.

Hasil analisis regresi berganda menunjukkan bahwa hipotesis $5\left(\mathrm{H}_{5}\right)$ memberikan hasil $\mathrm{H}_{0}$ ditolak dan $\mathrm{H}_{\mathrm{a}}$ diterima, berarti pengendalian diri, motivasi, perilaku belajar dan minat belajar berpengaruh terhadap tngkat pemahaman akuntansi secara simultan atau bersamasama. Hal ini menunjukkan bahwa semakin tinggi pengendalian diri, motivasi, perilaku belajar, dan minat belajar seorang mahasiswa akan mampu meningkatkan tingkat pemahaman akuntansi.

Pengendalian diri dan motivasi yang tinggi dalam proses pembelajaran akan mampu meningkatkan tingkat pemahaman akuntansi. Mahasiswa yang mempunyai dorongan untuk membiasakan belajar dengan baik akan mengarah pada suatu pembentukan sikap dalam bertindak. Untuk itu, penting adanya motivasi dari diri individu untuk terbiasa belajar secara tepat, efektif, dan efisien. Dengan motivasi yang baik tersebut, maka perilaku dan minat belajar yang baikpun dapat mendorong mahasiswa bersikap membiasakan diri dengan kegiatan positif, dan belajar yang lebih efektif sehingga tidak hanya sekedar memahami mata kuliah akuntansi tetapi juga menghasilkan prestasi dan nilai yang baik.

Penelitian ini sejalan dengan penelitian-penelitian terdahulu, seperti ; penelitian Sari (2013), Penelitian Linda dan Sugeng (2017), Penelitian Subowo dan Alien (2016), dan Penelitian Ishak (2013), yang menyatakan variabel independen pada penelitian ini berpengaruh secara simultan terhadap variabel dependen.

\section{Kesimpulan}

\section{KESIMPULAN DAN SARAN}

Berdasarkan hasil penelitian yang diuraikan di atas, maka dapat diambil beberapa kesimpulan sebagai berikut ;

1. Hasil Penelitian menunjukkan pengendalian diri berpengaruh terhadap tingkat pemahaman akuntansi. Hal ini dapat disimpulakan berarti dengan pengendalian diri yang benar, mahasiswa mampu memahami mata kuliah akuntansi dengan baik.

2. Hasil Penelitian menunjukkan motivasi berpengaruh terhadap tingkat pemahaman akuntansi. Hal ini dapat disimpulkan berarti dengan motivasi belajar yang tinggi maka akan mampu meningkatkan pemahaman mata kuliah akuntansi.

3. Hasil Penelitian menunjukkan perilaku belajar berpengaruh terhadap tingkat pemahaman akuntansi. Hal ini dapat disimpulkan bahwa perilaku belajar yang positif akan menimbulkan intensitas kegiatan yang lebih tinggi, mahasiswa yang sikap belajarnya positif akan belajar dengan aktif dengan demikian dapat meningkatkan pemahaman mata kuliah akuntansi.

4. Hasil Penelitian menunjukkan minat belajar tidak berpengaruh terhadap tingkat pemahaman akuntansi. Hal ini dapat disimpulkan bahwa dengan memungkinkan adanya keadaan dan kondisi sistem mengajar yang berbeda pada setiap mata kuliah akuntansi, dapat mempengaruhi kurang mintanya mahasiswa sehingga dapat berpengaruh menurunnya pemahaman akuntansi.

5. Hasil Penelitian menunjukkan semua variabel independen penelitian ini ; pengendalian diri, motivasi, perilaku belajar dan minat belajar berpengaruh secara simultan terhadap variabel dependen, yaitu ; tingkat pemahaman akuntansi.

Saran

Penelitian ini memiliki keterbatasan yaitu ; Penelitian ini hanya menggunakan kuisioner sebagai instrumen penelitian sehingga kesimpulan yang diambil hanya berdasarkan data yang dikumpulkan melalui kuisioner. Penelitian selanjutnya diharapkan tidak hanya menggunakan data kuisioner saja tetapi dapat menggunakan data wawancara sebagai instrumen penelitiannya, agar penelitian menjadi lebih lengkap dan mengatasi kelemahan-kelemahan yang mungkin terdapat pada metode kuisioner.

Adapun saran yang dapat dipertimbangkan agar tingkat pemahaman akuntansi kedepannya dapat lebih baik, yaitu ; khususnya untuk mahasiswa jurusan akuntansi, harus menyadari bahwa sangat penting untuk memahami mata kuliah akuntansi, tidak hanya sekedar duduk dan mendengarkan materi saja, tetapi dapat dengan meningkatkan pengendalian diri, menumbuhkan motivasi, perilaku belajar yang baik, serta minta belajar yang tinggi, agar dapat memahami dengan baik serta mencapai hasil belajar dan nilai yang baik pula. Dan bagi dosen, dapat meningkatkan sistem pembelajaran yang dapat menarik minat belajar mahasiswa, serta mendorong pengendalian diri, motivasi, dan perilaku 
belajar mahasiswa, agar dapat meningkatkan pemahaman dari mata kuliah khususnya mata kuliah akuntansi.

\section{REFERENSI}

[1] Andriani, R., Hamdani, N. A., \& Setiawan, R. (2020). THE EFFECT OF ENTREPRENEURSHIP KNOWLEDGE ON SELF EFFICACY AND ITS IMPACT ON STUDENTS ' INTERESTS. BIEJ: Business Innovation \& Entrepreneurship Journal, 2(2), 126-130.

[2] Tenisia, I., Sari, P., \& Sylvia, E. (2020). Analisis Karakteristik Mahasiswa dan Motivasi Belajar terhadap Prestasi Akademik Mahasiswa Entrepreneur Kabupaten Garut. BIEJ: Business Innovation \& Entrepreneurship Journal, 2(1), 28 40.

[3] Anggun. 2010. Pengaruh Kecerdasan Emosional Terhadap Tingkat Pemahaman Akuntansi. Jurnal Universitas Diponegoro.

[4] Arie, Pengestu Dwijayanti. 2009. Pengaruh Kecerdasan Emsional, Kecerdasan intelektual dan Kecerdasan Spiritual, dan Kecerasan Sosial Terhadap pemahaman Akuntansi. Skripsi. Universitas Pemabangunan Nasional "Veteran".

[5] Azwar, S. 2004. Pengantar Psikologi Intelegensi, Cetakan Kelima. Yogyakarta: Pustaka Pelajar

[6] Budhiyanto, Suryanti J. \& Nugroho, Ika P. 2004. "Pengaruh Kecerdasan Emosional terhadap Tingkat Pemahaman Akuntansi". Jurnal Ekonomi Bisnis, Vol. X, No.2, Hal. 260-281.

[7] Goleman, Daniel. 2001. Kecerdasan Emosional. Mengapa EQ lebih penting dari IQ. Jakarta: Penerbit Gramedia Pustaka Utama.

[8] Imam, Ghozali. 2011. Aplikasi Analisis Multivariate dengan Program SPSS. Badan Penerbit Universitas Diponegoro, Semarang.

[9] Ishak, 2013. Pengaruh Kecerdasan Emosional, Kecerdasan Spiritual dan Minat Belajar terhadap Pemahaman Akuntansi. (Studi pada Mahasiswa Akuntansi Universitas Brawijaya Malang Angkatan 2010). Universitas Brawijaya Malang.

[10] Jogiyanto. 2011. Metode Penelitian Bisnis. BPFE: Yogyakarta.
[11] Linda, Atik Rokhana, dan Sugeng, Sutrisno. 2016. Pengaruh Kecerdasan Emosiona, Perilaku Blejar, dan Minat Belajar Terhadap Tingkat Pemahaman Akuntansi (Studi Empiris Pada Mahasiswa Akuntansi Fakultas Ekonomi dan Bisnis Unstag Semarang). Jurnal Media Ekonomi dan Bisnis Untag Semarang.

[12] Link Kusioner https://docs.google.com/forms/d/1WOKH2t3GE HrfhxE8s5JTO7kEYEHaeU0HmcE63qyY/prefill

[13] Rissyo, Nurna Aziza. 2006. Pengaruh Kecerdasan Emosional Terhadap Tingkat Pemahaman Akuntansi, Kepercayaan Diri Sebagai Variabel Pemoderasi. SNA IX, Padang, 23-26 Agustus.

[14] Sari, Yola Komala. 2013. Pengaruh Pengendalian Diri dan Perilaku Belajar Terhadap Tingkat Pemahaman Pengantar Akuntansi. Jurnal Fakultas Ekonomi Universitas Negeri Padang.

[15] Subowo, dan Alien Aulia. 2016. Pengaruh Pengendalian Diri, Motivasi, Perilaku Belajar Terhadap Pemahaman Akuntansi Mahasiswa. Economic Education Analysis Journal. ISSN : 2252-6544.

[16] Sugiyono. 2011. Statistika Untuk Penelitian. Alfa Beta: Bandung.

[17] Sujianto, Agus Eko. 2009. Aplikasi Statistik dengan SPSS. Jakarta : Prestasi Pustaka.

[18] Suliyanto. 2011. Ekonomi Terapan : Teori dan Aplikasi dengan SPSS. Andi : Yogyakarta.

[19] Suwardjono. 2004. Perilaku Belajar di Perguruan Tinggi, Jurnal Akuntansi, edisi Maret.

[20] V. Wiratna, Suryani. 2015. SPSS Untuk Penelitian. Pustaka Baru Press : Yogyakarta. 